\title{
Usability Criteria for Multimedia Interactive Learning Based on Website in Mathematics for SMK
}

\author{
Moch. Sukardjo \\ Dept. of Education for Electrical Engineering \\ Faculty of Engineering, State University of Jakarta \\ Jakarta \\ msoekardjo@unj.ac.id
}

\author{
Lipur Sugiyanta \\ Dept. of Education for Informatics and Computer \\ Engineering/ Faculty of Engineering, State University of \\ Jakarta \\ lipurs@unj.ac.id
}

\begin{abstract}
Web usability, if evaluation done correctly, can significantly improve the quality of the website. Website containing multimedia for education should apply user interfaces that are both easy to learn and easy to use. Multimedia has big role in changing the mindset of a person in learning. Using multimedia, learners get easy to obtain information, adjust information and empower information. Therefore, multimedia is utilized by teachers in developing learning techniques to improve student learning outcomes. For students with self-directed learning, multimedia provides the ease and completeness of the courses in such a way that students can complete the learning independently both at school and at home without the guidance of teachers. The learning independence takes place in how students choose, absorb information, and follow the evaluation quickly and efficiently. The 2013 Curriculum 2013 for Vocational High School (SMK) requires teachers to create engaging teaching and learning activities that students enjoy in the classroom (also called invitation learning environment). The creation of learning activity environment is still problem for most teachers. Various researches reveal that teaching and learning activities will be more effective and easy when assisted by visual tools. Using multimedia, learning material can be presented more attractively that help students understand the material easily. The opposite is found in the learning activity environment who only rely on ordinary lectures. Usability is a quality level of multimedia with easy to learn, easy to use and encourages users to use it. The website Multimedia Interactive Learning for Mathematics SMK Class $X$ is targeted object. Usability website in Multimedia Interactive Learning for Mathematics SMK Class X is important indicators to measure effectiveness, efficiency, and student satisfaction to access the functionality of website. This usability measurement should be done carefully before the design is implemented thoroughly. The only way to get test with high quality results is to start testing at the beginning of the design process and continuously testing each of the next steps. This research performs usability testing on of website by using WAMMI criterion (Website Analysis and Measurement Inventory) and will be focused on how convenience using the website application. Components of Attractiveness, Controllability, Efficiency, Helpfulness, and Learnability are applied. The website in Multimedia Interactive Learning for Mathematics SMK Class $X$ can be in accordance with the purpose to be accepted by student to improve student learning outcomes. The results show that WAMMI method show the usability value of Multimedia Mathematics SMK Class X is about from $70 \%$ to $90 \%$.
\end{abstract}

Keywords-web; usability; WAMMI criteria; mathematics; self learning

\section{INTRODUCTION}

There are many things to consider when building a new website for education. Basically, the site needs to be attractive enough that students want to use it. It also needs to contain all of the materials that students need in order to help them achieve the objective for learning targets. One of the most important aspects of building a website is testing for usability. Internet users (students) are accustomed to being able to figure out how to use a website quickly. Most of them will not take the time to figure out a site that is not usable.

Usability is defined by the International Standard Organization as " the extent to which a product can be used by specified users to achieve specific goals with effectiveness, efficiency and satisfaction in a specified context of use"[1]. In [2], web usability is translated as how easy it is to learn, remember and use a web interface with minimum errors.

. The main reason that usability is so important is because there are so many similar websites that people will go to the next site if the first one they visit is not usable. Beautiful website may not achieve its objectives if users are unable to figure out how to navigate the site quickly. According to [3], users will return to a website only if the website can provide useful information that is easy to navigate in presented in a well-structured layout. In other words, the acceptance of a website depends on how easy it is to use the site to find helpful information. Web usability testing aims to determine whether a website is in accordance with the needs of the user (students) or not.

This research does usability testing on Website containing Multimedia Interactive Learning Based in Mathematics for SMK on by using field observation method is by observing users how they use the application. The website is not only a cost efficient and timely method to communicate with various students. That's vitality of usability issue for the websites. Usability is importance in terms of satisfying website users' needs and expectations. In this research, usability components tested consist of attractiveness, controllability, efficiency, 
helpfulness, and learnability. It also presents a description of two such methods developed by [1] and [2].

\section{RELATED RESEARCH}

The criteria used in the research of usability websites are quite diverse and vary from one journal to another. For example, the HHS guidelines proposed by Koyani et. al [4] list 187 extensive principles to assess the usability of informationoriented web sites, sourced from 375 cited publications. Another recommendation (the JISC) by Bevan and Kincla [5] provide the 121 guides to assess academic website usability. In this paper however, we refer to two guidelines as follows:

- "Assessing the Usability of University Websites: An Empirical Study on Namik Kemal University" [6]

- "Common Usability Problems on Educational Websites" [7]

[6] use five usability criteria defined by WAMMI (Website Analysis and Measurement Inventory). These criteria can be seen in table 1.

TABLE I. CRITERIA USED IN PAPER 1 “ASSESING THE USABILITY OF UNIVERSITY WEBSITES: AN EMPERICAL STUDY ON NAMIK KEMAL UNIVESITY"

\begin{tabular}{|l|l|}
\hline \multicolumn{1}{|c|}{ Criteria } & \multicolumn{1}{c|}{ Definition } \\
\hline Attractiveness & $\begin{array}{l}\text { Website have a visually pleasing appearance and can } \\
\text { draw the user's attention to visit the web. }\end{array}$ \\
\hline Controlability & $\begin{array}{l}\text { The level of control that a user perceives when a } \\
\text { person interacts with a website. The site with good } \\
\text { controlability enable users to navigate the website } \\
\text { easily and can do the things they want to do. }\end{array}$ \\
\hline Efficiency & $\begin{array}{l}\text { Users can achieve their target with a short visit } \\
\text { without the need to use a lot of cognitive effort. }\end{array}$ \\
\hline Helpfulness & $\begin{array}{l}\text { Website has the structure and content that matches } \\
\text { the expectations of users. }\end{array}$ \\
\hline Learnability & $\begin{array}{l}\text { Ease in the time and effort of users to learn the } \\
\text { website. }\end{array}$ \\
\hline
\end{tabular}

That research aims to measure the usability of the Namık Kemal University (NKU) web site via the five factors of usability: attractiveness, controllability, helpfulness, efficiency and learnability. The results reveal that the five usability factors are positively related with usability perception, i.e., attractiveness, helpfulness, efficiency, learnability, and controllability.

[7] uses five different criteria. The criteria used in the paper and its definition can be seen in table 2 below.

TABLE II. USABILITY CRITERIA FOR PAPER 2 “COMMON USABILITY PROBLEMS ON EDUCATIONAL WEBSITES”

\begin{tabular}{|l|l|}
\hline \multicolumn{1}{|c|}{ Criteria } & \multicolumn{1}{c|}{ Definition } \\
\hline Navigation & $\begin{array}{l}\text { Assessing whether a site has the tools and links that } \\
\text { facilitate user navigation on the site. }\end{array}$ \\
\hline Architecture & $\begin{array}{l}\text { Associated with the information structure where } \\
\text { the site structure is divided into logical groups and } \\
\text { each group contains related information. }\end{array}$ \\
\hline $\begin{array}{l}\text { Ease of use and } \\
\text { Communication }\end{array}$ & $\begin{array}{l}\text { Relates to the cognitive effort required to use a } \\
\text { website. }\end{array}$ \\
\hline Design & $\begin{array}{l}\text { Visual Attraction website, use of good design and } \\
\text { use of images, fonts, good color. }\end{array}$ \\
\hline
\end{tabular}

\begin{tabular}{|l|l|}
\hline \multicolumn{1}{|c|}{ Criteria } & \multicolumn{1}{|c|}{ Definition } \\
\hline Content & $\begin{array}{l}\text { Assessing whether a website already has the } \\
\text { information the user needs. }\end{array}$ \\
\hline
\end{tabular}

The criteria in Table 2 comprehensively evaluated the usability of three large public university websites in Jordan, using the heuristic evaluation method. The results identified a list of 34 specific types of common usability problems that were found on the selected Jordanian university websites, and described the frequency number of these problems. The results of 34 problems that were uniquely identified in this research included: Misleading links, links don't open the destination pages, links cause disappearance of the menu, broken links, various types of inconsistency problems, inappropriate orientation of the page design, ineffective text format, broken images, inappropriate choice of color, empty page, inappropriate content, difficult interaction with a website, and lack of support to the Arabic language.

Furthermore, the common and specific usability problems that were uniquely identified in that research, could be used as guidelines for universities in Jordan, to investigate and improve their universities' websites, and therefore to achieve the advantages of usable educational websites.

Therefore, given the different criteria used by the two papers, further studies were conducted by investigate and improve their educational websites followed by comparing the definitions of the two groups. Table 3 shows the results of the comparison:

\section{TABLE III. COMPARISON OF CRITERIA}

\begin{tabular}{|l|l|}
\hline \multicolumn{1}{|c|}{ Paper 1 } & \multicolumn{1}{|c|}{ Paper 2 } \\
\hline $\begin{array}{l}\text { Attractiveness: Website have a } \\
\text { visually pleasing appearance and } \\
\text { can draw the user's attention to } \\
\text { visit the web }\end{array}$ & $\begin{array}{l}\text { Design: Visual Attraction } \\
\text { website, use of good design and } \\
\text { use of images, fonts, good color. }\end{array}$ \\
\hline $\begin{array}{l}\text { Controlability: The level of } \\
\text { control that a user perceives when }\end{array}$ & $\begin{array}{l}\text { Navigation: Assessing whether a } \\
\text { a person interacts with a website. } \\
\text { The site with good controlability } \\
\text { enable users to navigate the } \\
\text { facilitate user navigation on the } \\
\text { site. } \\
\text { things they want to do. }\end{array}$ \\
\hline $\begin{array}{l}\text { Efficiency: Users can achieve their } \\
\text { target with a short visit without the } \\
\text { need to use a lot of cognitive } \\
\text { effort. }\end{array}$ & $\begin{array}{l}\text { Ease of use and Communication: } \\
\text { Relates to the cognitive effort } \\
\text { required to use a website. }\end{array}$ \\
\hline $\begin{array}{l}\text { Learnability: Ease in the time and } \\
\text { effort of users to learn the website. }\end{array}$ & $\begin{array}{l}\text { Architecture: Associated with the } \\
\text { information structure where the } \\
\text { site structure is divided into } \\
\text { logical groups and each group } \\
\text { contains related information. }\end{array}$ \\
\hline $\begin{array}{l}\text { Helpfulness: Website has the } \\
\text { structure and content that matches } \\
\text { the expectations of users. }\end{array}$ & $\begin{array}{l}\text { Content: Assessing whether a } \\
\text { website already has the } \\
\text { information the user needs. }\end{array}$ \\
\hline
\end{tabular}

Based on the review results of the two papers above, it is known that both groups of criteria have the similar form of definition but criteria in Paper 1 is more extensive coverage than Paper 2, therefore in this research, criteria in the Paper 1 will be used. 
The preliminary researh paper was presented at ICVEE (International Conference on Vocational and Electrical Engineering), Surabaya, on November 9, 2017.

\section{METHOD AND TOOLS}

Set up a website usability testing is carefully construct activities to build a scenario wherein a person performs a list of tasks that someone who is using the website for the first time is likely to perform. This form will be used to evaluate a product (in this case a website) by testing is on users (students). Researcher observes and listens to the students who is performing the tasks while taking notes. Watching students perform common tasks on a website is a great way to test whether the site is usable because quick response will immediately be able to see whether they are able to perform the tasks and any difficulties they have while doing so.

The following is a brief description of the main usability testing methods that are used.

TABLE IV. DESCRIPTION OF CRITERIA

\begin{tabular}{|c|c|c|}
\hline Main Criteria & $\begin{array}{c}\text { Sub- } \\
\text { Criteria }\end{array}$ & Definition \\
\hline \multirow[t]{6}{*}{ Attractiveness } & View & $\begin{array}{l}\text { Applied good resolution at least } 640 \times \\
480 \text {. } \\
\text { Can be viewed using mobile with a } \\
\text { resolution of } 1280 \times 800 \text { (HD) to } 320 \\
\text { x } 240 \text { (QVGA). }\end{array}$ \\
\hline & Color & $\begin{array}{l}\text { Color used is dominant cool color } \\
\text { (pastel color or grey color). }\end{array}$ \\
\hline & Font & $\begin{array}{l}\text { Selected of fonts is readable (Arial } 10- \\
15 \mathrm{pt} \text { or Calibri } 10-15 \mathrm{pt} \text { ). }\end{array}$ \\
\hline & Images & $\begin{array}{l}\text { Images have good quality that is type } \\
\text { PNG or type TIFF }\end{array}$ \\
\hline & Video & $\begin{array}{l}\text { Video is encoded with minimum } \\
\text { resolution of } 480 \mathrm{p}: 854 \times 480 \text {. }\end{array}$ \\
\hline & Animation & Animation embedded is not autoplay. \\
\hline \multirow[t]{2}{*}{ Controlability } & Design & $\begin{array}{l}\text { Website visualization is easy to } \\
\text { understand by users in the form of } \\
\text { buttons and links with no different } \\
\text { from the usual looking of Facebook. }\end{array}$ \\
\hline & $\begin{array}{l}\text { Menu } \\
\text { navigation }\end{array}$ & $\begin{array}{l}\text { Menus are grouped according to their } \\
\text { similarity. }\end{array}$ \\
\hline Efficiency & $\begin{array}{l}\text { Speed } \\
\text { launch/ } \\
\text { display }\end{array}$ & $\begin{array}{l}\text { Time needed to load/display the entire } \\
\text { web in a short time from the beginning } \\
\text { of the click (is ranging from } 1-5 \text { to } 21- \\
25 \text { second). }\end{array}$ \\
\hline Learnability & Ease of use & $\begin{array}{l}\text { Users can use the website without any } \\
\text { constraints even though it has not } \\
\text { opened for } 1 \text { month. }\end{array}$ \\
\hline Helpfulness & $\begin{array}{l}\text { Content } \\
\text { architecture }\end{array}$ & $\begin{array}{l}\text { Information is divided into logical } \\
\text { groups and each group contains } \\
\text { updated regularly. }\end{array}$ \\
\hline
\end{tabular}

The criteria above need to be quantitative to make student's perceptions on usability of website could be analyzed. This quantitative fulfillment restriction is useful for each sub-criteria to have a maximum and a minimum constraints response that can be fulfilled. The limits used letters A-B-C-D-E, each representing the mark of the criteria. The letter " $\mathrm{A}$ " representing the best rating of fulfillment and the lowest rating represented by letter "E". Students will provide value in accordance with column that has been provided. The table 5 below is the criteria and quantitative description of usability website used in the research.

TABLE V. DESCRIPTION OF CRITERIA

\begin{tabular}{|c|c|c|c|c|c|c|}
\hline $\begin{array}{c}\text { Main } \\
\text { Criteria }\end{array}$ & $\begin{array}{c}\text { Sub- } \\
\text { Criteria }\end{array}$ & $\mathbf{A}$ & B & C & D & $\mathbf{E}$ \\
\hline \multirow[t]{6}{*}{$\begin{array}{l}\text { Attractive } \\
\text { ness }\end{array}$} & View & $\begin{array}{l}\text { Websit } \\
\text { e use } \\
1280 \times 8 \\
00 \\
\text { resoluti } \\
\text { on } \\
\text { Could } \\
\text { open } \\
\text { via } \\
\text { mobile } \\
\text { with } \\
1280 x 7 \\
20 \\
\text { resoluti } \\
\text { on } \\
\text { (HD) }\end{array}$ & $\begin{array}{l}\text { Websit } \\
\text { e use } \\
1024 \times 7 \\
68 \\
\text { resoluti } \\
\text { on } \\
\text { Could } \\
\text { open } \\
\text { via } \\
\text { mobile } \\
\text { with } \\
960 x 54 \\
0 \\
\text { resoluti } \\
\text { on } \\
\text { (HD) }\end{array}$ & $\begin{array}{l}\text { Websit } \\
\text { e use } \\
1024 \times 6 \\
00 \\
\text { resoluti } \\
\text { on } \\
\text { Could } \\
\text { open } \\
\text { via } \\
\text { mobile } \\
\text { with } \\
800 x 60 \\
0 \\
\text { resoluti } \\
\text { on } \\
\text { (SVGA } \\
\text { ) }\end{array}$ & $\begin{array}{l}\text { Websit } \\
\text { e use } \\
800 \times 60 \\
0 \\
\text { resoluti } \\
\text { on } \\
\text { Could } \\
\text { open } \\
\text { via } \\
\text { mobile } \\
\text { with } \\
640 x 48 \\
0 \\
\text { resoluti } \\
\text { on } \\
\text { (VGA) }\end{array}$ & $\begin{array}{l}\text { Websit } \\
\text { e use } \\
640 x 48 \\
0 \\
\text { resoluti } \\
\text { on } \\
\text { Could } \\
\text { open } \\
\text { via } \\
\text { mobile } \\
\text { with } \\
320 x 24 \\
0 \\
\text { resoluti } \\
\text { on } \\
\text { (QVG } \\
\text { A) }\end{array}$ \\
\hline & Color & $\begin{array}{l}\text { Domin } \\
\text { ant } \\
\text { color is } \\
\text { cool } \\
\text { (green, } \\
\text { blue, } \\
\text { purple) }\end{array}$ & $\begin{array}{l}\text { Domin } \\
\text { ant } \\
\text { color is } \\
\text { warm } \\
\text { (red, } \\
\text { yellow, } \\
\text { orange) }\end{array}$ & $\begin{array}{l}\text { Domin } \\
\text { ant } \\
\text { color is } \\
\text { neutral } \\
\text { (chocol } \\
\text { ate, } \\
\text { grey) }\end{array}$ & $\begin{array}{l}\text { Domin } \\
\text { ant } \\
\text { color is } \\
\text { black } \\
\text { and } \\
\text { white }\end{array}$ & $\begin{array}{l}\text { Domin } \\
\text { ant } \\
\text { color is } \\
\text { black }\end{array}$ \\
\hline & Font & $\begin{array}{l}\text { Arial } \\
\text { size } \\
10-15\end{array}$ & $\begin{array}{l}\text { Open } \\
\text { Sans } \\
\text { size } \\
10-15\end{array}$ & $\begin{array}{l}\text { Times } \\
\text { New } \\
\text { Roman } \\
\text { size } \\
10-15\end{array}$ & $\begin{array}{l}\text { Verdan } \\
\text { a size } \\
10-15\end{array}$ & $\begin{array}{l}\text { Calibri } \\
\text { size } \\
10-15\end{array}$ \\
\hline & Images & $\begin{array}{l}\text { Format } \\
\text { PNG } \\
\text { (Portab } \\
\text { le } \\
\text { Networ } \\
\text { k } \\
\text { Graphi } \\
\text { cs) }\end{array}$ & $\begin{array}{l}\text { Format } \\
\text { JPEG } \\
\text { (Join } \\
\text { Photog } \\
\text { raphics } \\
\text { Expert } \\
\text { Groups } \\
\text { ) }\end{array}$ & $\begin{array}{l}\text { Format } \\
\text { JPG }\end{array}$ & $\begin{array}{l}\text { Format } \\
\text { BMP }\end{array}$ & $\begin{array}{l}\text { Format } \\
\text { TIFF } \\
\text { (Tagge } \\
\text { d } \\
\text { Imaged } \\
\text { Format } \\
\text { File) }\end{array}$ \\
\hline & Video & $\begin{array}{l}\text { Format } \\
\text { MKV, } \\
\text { MOV }\end{array}$ & $\begin{array}{l}\text { Format } \\
\text { MP4 }\end{array}$ & $\begin{array}{l}\text { format } \\
\text { WMV }\end{array}$ & $\begin{array}{l}\text { Format } \\
\text { FLV, } \\
\text { SWF }\end{array}$ & $\begin{array}{l}\text { Format } \\
\text { AVI, } \\
\text { MPEG, } \\
\text { 3GP }\end{array}$ \\
\hline & $\begin{array}{l}\text { Animati } \\
\text { on }\end{array}$ & $\begin{array}{l}\text { Format } \\
\text { 3D }\end{array}$ & $\begin{array}{l}\text { Format } \\
\text { SWF, } \\
\text { SWI }\end{array}$ & $\begin{array}{l}\text { Format } \\
\text { EXE }\end{array}$ & $\begin{array}{l}\text { Format } \\
\text { PPTX }\end{array}$ & $\begin{array}{l}\text { Format } \\
\text { GIF }\end{array}$ \\
\hline \multirow[t]{2}{*}{$\begin{array}{l}\text { Controlabi } \\
\text { lity }\end{array}$} & Design & $\begin{array}{l}\text { Button } \\
\text { underli } \\
\text { ned, } \\
\text { Pointer } \\
\text { hover }\end{array}$ & $\begin{array}{l}\text { Button } \\
\text { in } \\
\text { individ } \\
\text { ual } \\
\text { frame, } \\
\text { Pointer } \\
\text { hover }\end{array}$ & $\begin{array}{l}\text { Pointer } \\
\text { hover }\end{array}$ & $\begin{array}{l}\text { Pointer } \\
\text { change } \\
\text { size }\end{array}$ & $\begin{array}{l}\text { No } \\
\text { effect }\end{array}$ \\
\hline & $\begin{array}{l}\text { Menu } \\
\text { navigati } \\
\text { on }\end{array}$ & $\begin{array}{l}\text { Groupe } \\
\text { d } \\
\text { accordi } \\
\text { ng to } \\
\text { head } \\
\text { menu }\end{array}$ & $\begin{array}{l}\text { Groupe } \\
\text { d }\end{array}$ & $\begin{array}{l}\text { Some } \\
\text { are } \\
\text { groupe } \\
\text { d }\end{array}$ & $\begin{array}{l}\text { Few } \\
\text { are } \\
\text { groupe } \\
\text { d }\end{array}$ & None \\
\hline Efficiency & $\begin{array}{l}\text { Speed } \\
\text { launch/ } \\
\text { display }\end{array}$ & $\begin{array}{l}1-5 \\
\text { secs }\end{array}$ & $\begin{array}{l}6-10 \\
\text { secs }\end{array}$ & $\begin{array}{l}11-15 \\
\text { secs }\end{array}$ & $\begin{array}{l}16-20 \\
\text { secs }\end{array}$ & $\begin{array}{l}21-25 \\
\text { secs }\end{array}$ \\
\hline $\begin{array}{l}\text { Learnabilit } \\
\mathrm{y}\end{array}$ & $\begin{array}{l}\text { Ease of } \\
\text { use }\end{array}$ & $\begin{array}{l}\text { Users } \\
\text { capable } \\
\text { using } \\
\text { the }\end{array}$ & $\begin{array}{l}\text { Users } \\
\text { capable } \\
\text { using } \\
\text { the }\end{array}$ & $\begin{array}{l}\text { Users } \\
\text { capable } \\
\text { using } \\
\text { the }\end{array}$ & $\begin{array}{l}\text { Users } \\
\text { capable } \\
\text { using } \\
\text { the }\end{array}$ & $\begin{array}{l}\text { Users } \\
\text { capable } \\
\text { using } \\
\text { the }\end{array}$ \\
\hline
\end{tabular}




\begin{tabular}{|c|c|c|c|c|c|c|}
\hline $\begin{array}{c}\text { Main } \\
\text { Criteria }\end{array}$ & $\begin{array}{c}\text { Sub- } \\
\text { Criteria }\end{array}$ & $\mathbf{A}$ & B & C & D & $\mathbf{E}$ \\
\hline & & $\begin{array}{l}\text { website } \\
\text { after } \\
30 \\
\text { days }\end{array}$ & $\begin{array}{l}\text { website } \\
\text { after } \\
20 \\
\text { days }\end{array}$ & $\begin{array}{l}\text { website } \\
\text { after } \\
15 \\
\text { days }\end{array}$ & $\begin{array}{l}\text { website } \\
\text { after } \\
10 \\
\text { days }\end{array}$ & $\begin{array}{l}\text { website } \\
\text { after } 7 \\
\text { days }\end{array}$ \\
\hline $\begin{array}{l}\text { Helpfulnes } \\
\text { s }\end{array}$ & $\begin{array}{l}\text { Content } \\
\text { architect } \\
\text { ure }\end{array}$ & $\begin{array}{l}\text { Update } \\
\text { d } \\
\text { regular } \\
\text { ly } \\
\text { every } 3 \\
\text { days }\end{array}$ & $\begin{array}{l}\text { Update } \\
\text { d } \\
\text { regular } \\
\text { ly } \\
\text { every } 5 \\
\text { days }\end{array}$ & $\begin{array}{l}\text { Update } \\
\text { d } \\
\text { regular } \\
\text { ly } \\
\text { every } \\
\text { week }\end{array}$ & $\begin{array}{l}\text { Update } \\
\text { d } \\
\text { regular } \\
\text { ly } \\
\text { every } \\
\text { month }\end{array}$ & $\begin{array}{l}\text { Update } \\
\text { d } \\
\text { regular } \\
\text { ly } \\
\text { every } 2 \\
\text { months }\end{array}$ \\
\hline
\end{tabular}

The website become research object is named http://www.sukardjo-lipurs.com. The website usability testing was using the famous browser Google Chrome. In terms of this test, only 3 pages from the website will be tested. Almost all of usability criteria were evaluated through visual or eyesight not get into the elements of the website source code. Students and 3 expert (teachers) are involved during this testing. Several criteria require a period to complete the usability testing. Researcher also perform testing using online tools to measure of a website portfolio. The chosen online tools are responsivepx.com; fontface.Ninja; and pingdom (https://tools.pingdom.com/). For helpfulness, these sub-criteria is verified with 16-item questionnaire was administered manually using PSSUQ (Post-Study Usability Questionnaire) template.

Website usability testing was conducted on 27 July 2017 until 10 September 2017. The research was conducted in SMKN 39 Jakarta Pusat.

\section{RESULT AND ANALYSIS}

The result of the website usability testing based on criteria showed in table 6 below.

TABLE VI. RESUlt OF TESTING

\begin{tabular}{|l|l|c|}
\hline Main Criteria & \multicolumn{1}{|c|}{ Sub-Criteria } & Result \\
\hline \multirow{5}{*}{ Attractiveness } & View & A \\
\cline { 2 - 3 } & Color & A \\
\cline { 2 - 3 } & Font & A \\
\cline { 2 - 3 } & Images & B \\
\cline { 2 - 3 } & Video & A \\
\cline { 2 - 3 } & Animation & A \\
\hline \multirow{3}{*}{ Controlability } & Design & B \\
\cline { 2 - 3 } & Menu navigation & B \\
\hline Efficiency & Speed launch/ display & A \\
\hline Learnability & Ease of use & B \\
\hline Helpfulness & Content architecture & A \\
\hline & & B \\
\hline
\end{tabular}

\section{A. Usability Website of Attractiveness}

Website has been using the resolution of $1280 \times 800$ then the rating is " $\mathrm{A}$ ". The screenshot view using responsivepx.com is given below. Website can be accessed via mobile (Smart Phone) with the best size $1280 \times 720$ (HD) hence the rating is "A".

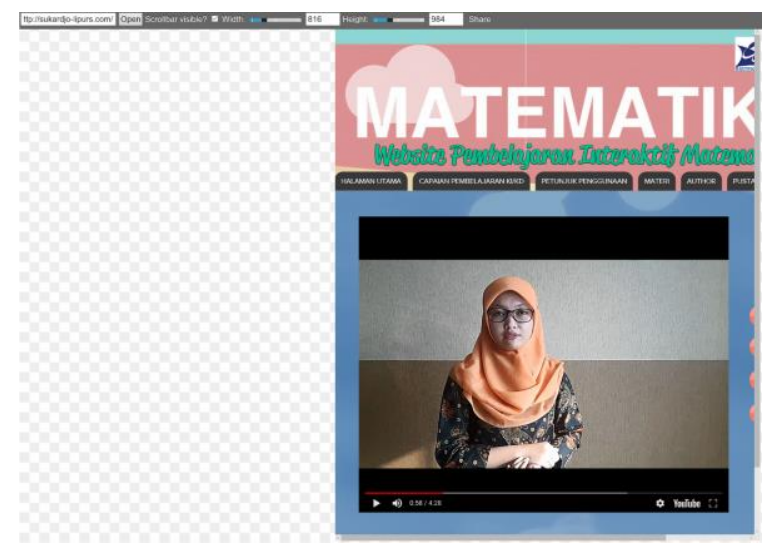

Fig. 1. Website view using http://responsivepx.com/?sukardjolipurs.com\%2F\#816x984\&scrollbars

The " $A$ " was marked on sub-criteria for color because the dominant color in the homepage of the website is cool (blue and green). Psychologically, the cool color is able to attract the attention of users because of its beauty and cool mind for whom views the website.

Mark "B" on the sub-criteria Fonts because the selection of fonts from the website in accordance with the website in the academic world, (most of) using "Open Sans" font size 1013pt. This font has a distinctive feature as a clear, easy to read and often used by students in academic activities. Verification of this font using software called "font face ninja".

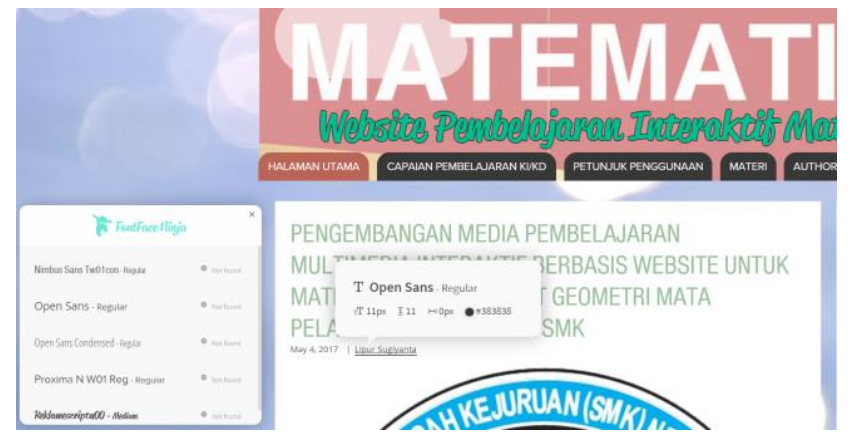

Fig. 2. Font view using FontFace Ninja.

\section{B. Usability Website of Controlability}

Mark " $B$ " on the design sub-criteria because the navigation on the website can be distinguished by the frame limit that as shown below Fig. 3. The key menu and navigation is easy to understand because it uses language commonly used by most websites and textbooks. Navigation buttons position is designed stay in place even though visitors move pages of the website.

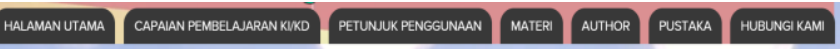

Fig. 3. Font view using FontFace Ninja 


\section{Usability Website of Efficiency}

Mark " $\mathrm{B}$ " in the sub-criteria loading time obtained from the testers using online tools called pingdom (https://tools.pingdom.com/). This tool is useful to measure time required (seconds) for the entire website to load. The result of loading time website is $6,38 \mathrm{~s}$ with capacity of website size equal to $15,7 \mathrm{MB}$.

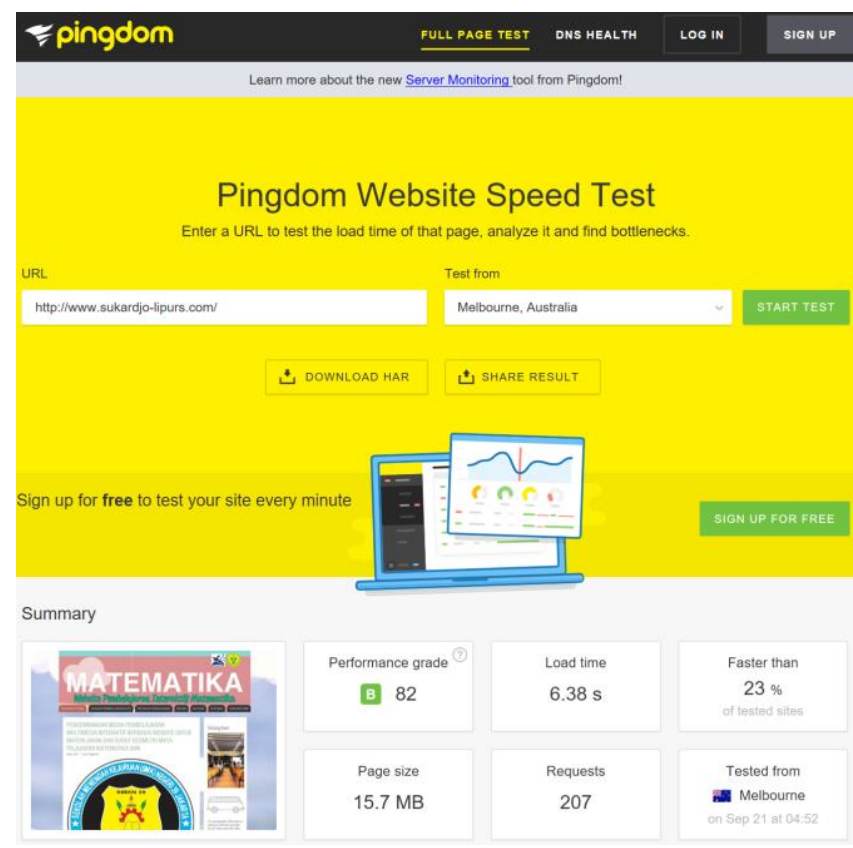

Fig. 4. Navigation button grouped in frame

\section{Usability Website of Learnability}

Learnability is defined as the capability of a website to enable the student to learn how to use it. This is a key usability feature that is often disregarded. In this case, the testing whether website is learnable is over a certain period (month or week), using the same students testing the interface multiple times at regular intervals. A more learnable website is one that reduces the time it takes to complete tasks as users spend more time with a website faster than others. These sub-criteria are marked with "A". Student can use the website even though not open for 30 days. That website rank relies on the familiarity and simplicity design.

\section{E. Usability Website of Helpfulness}

Helpfulness is degree to which students feel that the site enables them to solve their problems with finding information and navigating. Website is updated regularly every 5 days. This sub-criterion is marked with "B". Students find the website attractive, and also find it helpful.

This sub-criteria is verified with 16-item questionnaire was administered manually using PSSUQ (Post-Study Usability Questionnaire) template. The PSSUQ is a 16-item survey that measures users' perceived satisfaction with a product or system. Obtaining an overall satisfaction score is done by averaging the four sub-scales of System Quality (the average of items 1-6), Information Quality (the average of items 7-12), and Interface Quality (the average of items 13-16). The PSSUQ is highly reliable (.94) and is entirely free. (https://chaione.com/blog/ux-research-standardizing-usabilityquestionnaires/)

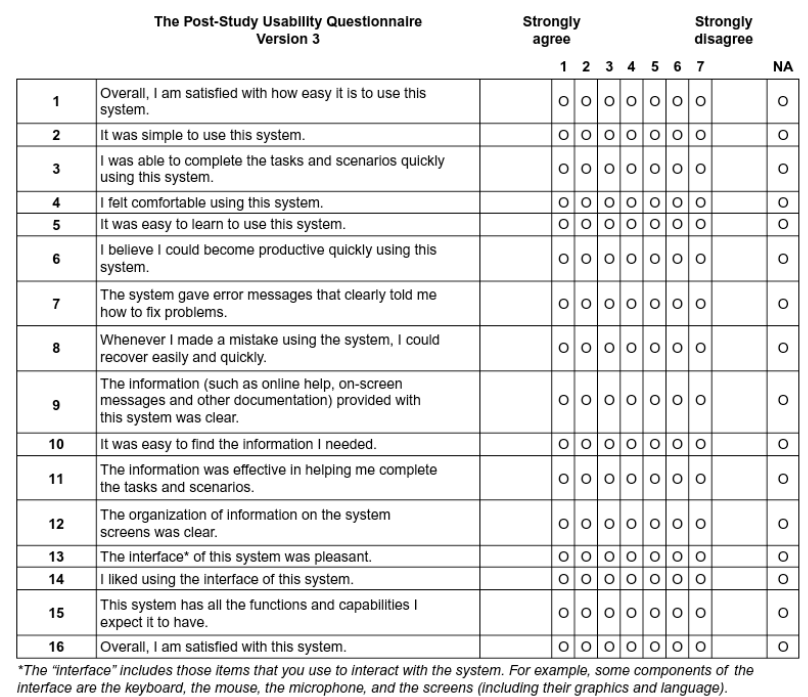

Fig. 5. PSSUQ survey.

Using PSSUQ instrument, the questionnaire was distributed to 10 respondents chosen from the sample, i.e. students and teachers who have used the website online. From the answers, all questions were answered validly. Reply of the questionnaires produce an output shows in Fig. 6 .

\begin{tabular}{|c|c|c|c|c|c|c|c|c|}
\hline \multirow{3}{*}{ 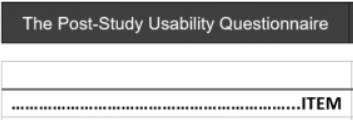 } & \multicolumn{2}{|c|}{$\begin{array}{l}\text { Strongly } \\
\text { Agree }\end{array}$} & \multicolumn{5}{|c|}{$\begin{array}{c}\text { Strongly } \\
\text { Disagree }\end{array}$} & \multirow{3}{*}{ Total Respond } \\
\hline & \multicolumn{7}{|c|}{ Selected Answer } & \\
\hline & 1 & 2 & 3 & 4 & 5 & 6 & 7 & \\
\hline 1 & 5 & 3 & 2 & 0 & 0 & 0 & 0 & $100 \%$ \\
\hline 2 & 7 & 3 & 0 & 0 & 0 & 0 & 0 & $100 \%$ \\
\hline 3 & 2 & 8 & 0 & 0 & 0 & 0 & 0 & $100 \%$ \\
\hline 4 & 0 & 8 & 2 & 0 & 0 & 0 & 0 & $100 \%$ \\
\hline 5 & 3 & 6 & 1 & 0 & 0 & 0 & 0 & $90 \%$ \\
\hline 6 & 7 & 3 & 0 & 0 & 0 & 0 & 0 & $100 \%$ \\
\hline 7 & 0 & 0 & 0 & 0 & 7 & 3 & 0 & $100 \%$ \\
\hline 8 & 0 & 0 & 0 & 6 & 4 & 0 & 0 & $100 \%$ \\
\hline 9 & 2 & 6 & 2 & 0 & 0 & 0 & 0 & $100 \%$ \\
\hline 10 & 4 & 5 & 0 & 0 & 0 & 10 & 0 & $100 \%$ \\
\hline 11 & 0 & 2 & 7 & 1 & 0 & 0 & 0 & $100 \%$ \\
\hline 12 & 1 & 9 & 0 & 0 & 0 & 0 & 0 & $100 \%$ \\
\hline 13 & 1 & 8 & 1 & 0 & 0 & 0 & 0 & $100 \%$ \\
\hline 14 & 2 & 7 & 1 & 0 & 0 & 0 & 0 & $100 \%$ \\
\hline 15 & 4 & 6 & 0 & 0 & 0 & 0 & 0 & $100 \%$ \\
\hline 16 & 7 & 3 & 0 & 0 & 0 & 0 & 0 & $100 \%$ \\
\hline
\end{tabular}

Fig. 6. Quetionaires results of PSSUQ survey.

Data processing produces the users' interpretation of $70 \%$ satisfaction with the website. This satisfaction is based on the simplicity of the application (>70\%), ease of use (>70\%), application response to errors (>70\%), appropriate content (> $70 \%$ ) and pleasant interface $>80 \%$ ). The results of data processing are as follows: 
TABLE VII. RESULT OF PSSUQ SURVEY

\begin{tabular}{|c|c|}
\hline $\begin{array}{l}\text { The Post-Study } \\
\text { Usability } \\
\text { Questionnaire }\end{array}$ & Result \\
\hline $\begin{array}{l}\text { Overall, I am } \\
\text { satisfied with how } \\
\text { easy it is to use this } \\
\text { system }\end{array}$ & $\begin{array}{l}\text { From } 10 \text { respondents, } 5 \text { people }(50 \%) \text { chose } \\
\text { the item "1", } 3 \text { people ( } 30 \%) \text { chose item "2" } \\
\text { and } 1 \text { person }(20 \%) \text { chose item "3". } \\
\text { It can be said for item "1" generally satisfied } \\
\text { enough. }\end{array}$ \\
\hline $\begin{array}{l}\text { It was simple to use } \\
\text { this system }\end{array}$ & $\begin{array}{l}\text { From } 10 \text { respondents, } 7 \text { people }(70 \%) \text { chose } \\
\text { the item "1", } 3 \text { people }(30 \%) \text { chose the item } \\
\text { "2". } \\
\text { It can be said for item " } 2 \text { " generally the } \\
\text { website used is quite simple. }\end{array}$ \\
\hline $\begin{array}{l}\text { I could complete the } \\
\text { tasks and scenarios } \\
\text { quickly using this } \\
\text { system }\end{array}$ & $\begin{array}{l}\text { From } 10 \text { respondents, } 2 \text { people }(20 \%) \text { chose } \\
\text { item "1", } 8 \text { people }(80 \%) \text { chose item "2". } \\
\text { It can be said for item " } 3 \text { " generally learning } \\
\text { task can be quickly can be done after using } \\
\text { this website. }\end{array}$ \\
\hline $\begin{array}{l}\text { I felt } \\
\text { using }\end{array}$ & $\begin{array}{l}\text { From } 10 \text { respondents, } 8 \text { people }(80 \%) \text { chose } \\
\text { the item " } 2 \text { " and } 2 \text { people }(20 \%) \text { chose item } \\
\text { " } 3 " . \\
\text { It can be said for item " } 4 \text { " the website is very } \\
\text { convenient. }\end{array}$ \\
\hline $\begin{array}{l}\text { It wa } \\
\text { use th }\end{array}$ & $\begin{array}{l}\text { From } 10 \text { respondents, } 30 \text { people }(30 \%) \text { chose } \\
\text { the item "1", } 6 \text { people }(60 \%) \text { chose item "2" } \\
\text { and } 1 \text { person }(10 \%) \text { chose item "3". } \\
\text { It can be said for item "5" generally very } \\
\text { easy to use this website. }\end{array}$ \\
\hline $\begin{array}{l}\text { I believe I could } \\
\text { become productive } \\
\text { quickly using this } \\
\text { system }\end{array}$ & $\begin{array}{l}\text { From } 10 \text { respondents, } 7 \text { people }(70 \%) \text { chose } \\
\text { the item " } 1 \text { " and } 3 \text { people ( } 30 \%) \text { chose item } \\
\text { "2". } \\
\text { It can be said for item " } 6 \text { " the website is very } \\
\text { productive. }\end{array}$ \\
\hline $\begin{array}{l}\text { The system gave } \\
\text { error messages that } \\
\text { clearly told me how } \\
\text { to fix problems }\end{array}$ & $\begin{array}{l}\text { From } 10 \text { respondents, } 7 \text { people }(70 \%) \text { chose } \\
\text { the item " } 5 \text { " and } 3 \text { people ( } 30 \%) \text { chose item } \\
\text { "6". } \\
\text { It can be said for item "7" generally website } \\
\text { show a clear error message when there is a } \\
\text { problem. }\end{array}$ \\
\hline $\begin{array}{l}\text { Whenever I made a } \\
\text { mistake using the } \\
\text { system, I could } \\
\text { recover easily and } \\
\text { quickly }\end{array}$ & $\begin{array}{l}\text { Similar with question } 7 \text { that the majority of } \\
\text { respondents stated whether appear a misuse, } \\
\text { it is easy to fix. } 6 \text { people }(60 \%) \text { answered } \\
\text { item "5" and } 4 \text { people }(40 \%) \text { answered } \\
\text { answer "5". } \\
\text { It can be said that if there are errors of use } \\
\text { then it is easy to fix it. }\end{array}$ \\
\hline $\begin{array}{l}\text { The information } \\
\text { (such as online help, } \\
\text { on-screen messages } \\
\text { and other } \\
\text { documentation) } \\
\text { provided with system } \\
\text { was clear }\end{array}$ & $\begin{array}{l}\text { From } 10 \text { respondents, } 2 \text { persons ( } 20 \%) \text { chose } \\
\text { the item " } 1 ", 6 \text { people }(60 \%) \text { chose the item } \\
\text { "2" and } 2 \text { people }(20 \%) \text { chose item " } 3 " \text {. } \\
\text { It can be said for item "1" information } \\
\text { submitted in website is clear. }\end{array}$ \\
\hline $\begin{array}{l}\text { It was easy for me to } \\
\text { find the information I } \\
\text { needed }\end{array}$ & $\begin{array}{l}\text { From } 10 \text { respondents, } 4 \text { people ( } 40 \% \text { ) chose } \\
\text { the item " } 1 ", 50 \text { people }(50 \%) \text { chose the item } \\
\text { "2" and } 1 \text { person }(10 \%) \text { chose the item "6". } \\
\text { It can be said for item "1" that } 90 \% \text { of } \\
\text { respondents said it is very easy to get the } \\
\text { required information. }\end{array}$ \\
\hline $\begin{array}{l}\text { The information was } \\
\text { effective in helping } \\
\text { me complete the } \\
\text { tasks and scenarios }\end{array}$ & $\begin{array}{l}\text { From } 10 \text { respondents, } 2 \text { persons }(20 \%) \text { chose } \\
\text { the item "1", } 7 \text { people }(70 \%) \text { chose item "3" } \\
\text { and } 1 \text { person }(10 \%) \text { chose item " } 4 " \text {. } \\
\text { It can be said for item "1" that } 90 \% \text { of } \\
\text { participants say information is complete } \\
\text { enough to help learning tasks. }\end{array}$ \\
\hline $\begin{array}{l}\text { The organization of } \\
\text { information on the } \\
\text { system screens was } \\
\text { clear }\end{array}$ & $\begin{array}{l}\text { From } 10 \text { respondents, } 9 \text { people }(90 \%) \text { chose } \\
\text { the item "1", } 1 \text { person }(10 \%) \text { selects item } \\
\text { "2". } \\
\text { It can be said for item " } 1 \text { " generally the } \\
\text { organization of website on the screen quite }\end{array}$ \\
\hline
\end{tabular}

\begin{tabular}{|l|l|}
\hline \multicolumn{1}{|c|}{$\begin{array}{c}\text { The Post-Study } \\
\text { Usability } \\
\text { Questionnaire }\end{array}$} & Result \\
\hline $\begin{array}{l}\text { The interface* of this } \\
\text { system was pleasant }\end{array}$ & $\begin{array}{l}\text { From 10 respondents, 1 person (10\%) selects } \\
\text { item "1", 8 people (80\%) selects item "2" } \\
\text { and 1 person (10\%) selects item "3". } \\
\text { It can be said for item "1" interface in this } \\
\text { website is fun. }\end{array}$ \\
\hline $\begin{array}{l}\text { I liked using the } \\
\text { interface of this } \\
\text { system }\end{array}$ & $\begin{array}{l}\text { From 10 respondents, 2 persons (20\%) chose } \\
\text { item "1", 7 people (70\%) chose item "2" and } \\
\text { 1 person (10\%) chose item "3". } \\
\text { It can be said for item "1" that the } \\
\text { participants really like to use interface in this } \\
\text { website program. }\end{array}$ \\
\hline $\begin{array}{l}\text { This system has all } \\
\text { the functions and } \\
\text { capabilities I expect } \\
\text { it to have }\end{array}$ & $\begin{array}{l}\text { From 10 respondents, 4 people (40\%) chose } \\
\text { the item "1", 6 people (60\%) chose the item } \\
\text { "2". } \\
\text { It can be said for item "1" that program in } \\
\text { website got function and capability as } \\
\text { expected. }\end{array}$ \\
\hline $\begin{array}{l}\text { Overall, I am } \\
\text { satisfied with this } \\
\text { system }\end{array}$ & $\begin{array}{l}\text { From 10 respondents, 7 people (70\%) chose } \\
\text { the item "1", 3 people (30\%) chose the item } \\
\text { "2". } \\
\text { It can be said for item "1" that user feel } \\
\text { satisfied with this website. }\end{array}$ \\
\hline
\end{tabular}

\section{CONCLUSION}

Web usability is how easy a website is to use. The website has fulfilled usability testing aimed to determine whether a website is in accordance with the needs of the user (students) or not. The website https://www.sukardjo-lipurs.com/ in usability testing achieved from $70 \%$ to $90 \%$ of the criteria (Attractiveness $=$ almost $\mathrm{A}$, Controllability $=$ almost $\mathrm{A}$, Efficiency $=$ B, Helpfulness = B, Learnability = A). Therefore, this website is qualified in order to be used in research to assess the effectiveness of self-learning using the website.

\section{ACKNOWLEDGMENT}

We would like to express our sincere gratitude to our Dean, DR. Agus Dudung, M.Pd for the continuous support of research, for his patience, motivation, enthusiasm, and immense knowledge. His guidance helped us in all the time of research and writing of this paper. Our sincere thanks also go to principal of SMKN 39 Jakarta, teachers and students of $10^{\text {th }}$ grade for offering us the opportunities to conduct research in their school and leading us working on exciting projects.

\section{REFERENCES}

[1] N. Bevan, "Human-computer interaction standards," Adv. Hum. Factors Ergonomics, vol. 20, pp. 885-890, 1995.

[2] B. Battleson, A. Booth, and J. Weintrop, "Usability testing of an academic library web site: a case study," J. Acad. Librariansh., vol. 27, no. 3, pp. 188-198, 2001.

[3] M. Matera, F. Rizzo, and G. T. Carughi, "Web usability: Principles and evaluation methods," in Web engineering, Springer, 2006, pp. 143-180.

[4] S. J. Koyani et al., based web design \& usability guidelines. National Cancer Institute, 2004.

[5] N. Bevan and S. Kincla, HCI design foundation study. JISC. http://www. jisc. ac. uk/index. cfm, 2004.

[6] A. P. D. S. Ahmet Mentes and A. P. D. Aykut H. Turan, "ASSESSING THE USABILITY OF UNIVERSITY WEBSITES: AN EMPIRICAL STUDY ON NAMIK KEMAL UNIVERSITY," TOJET: The Turkish Online Journal of Educational Technology volume 11 Issue 3 , pp. 6169, July 2012. 
[7] S. T. Dave Lawrence, Balanced Website Design (Optimising Aesthetics, Usability and Purpose), London: Springer, 2007.

[8] I. J. Dewanto, Web Desain Metode Aplikasi dan Implementasi, Yogyakarta: Graha Ilmu, 2006.

[9] L. Hasan and E. Abuelrub, "Common Usability Problems on Educational Websites," in International Conference on Education and Education Technologies, Greece, 2003. 